\title{
Effect of waterlogging tolerance in wheat (Tritium aestivum L.) at ear emer- gence stage on growth, biochemical and yield parameters in sodic soil
}

\author{
Vinaya Kumar Yadav', Mamta Kajla ${ }^{2}$, S. P. Singh ${ }^{1}$, A. K. Singh ${ }^{1}$, R. K. Yadav ${ }^{1}$, Ajeet \\ Kumar Dwivedi ${ }^{1}$ \\ ${ }^{1}$ Narendra Deva University of Agriculture and Technology, Kumarganj, Faizabad-224229 (U.P.), INDIA \\ ${ }^{2}$ ICAR- Indian Institute of Wheat and Barley Research, Karnal-132001 (Haryana), INDIA \\ Corresponding author. E-mail: vinayayadav1988@gmail.com
}

Received: March 14, 2015; Revised received: October 4, 2015; Accepted: November 20, 2015

\begin{abstract}
Globally more than one-third of the irrigated area is under waterlogging which limits our wheat production and out of which northern Indo-Gangetic plains of India alone had 2.5 million ha affected by irregular waterlogging. So, to meet out the food demand of ever-growing population we have to find some alternates to harness the potential of the waterlogged area. With this point of view this investigation was conducted to study the changes in growth and biochemical behavior of wheat due to waterlogging at ear emergence stage in sodic soil and also to assess the traits conferring higher yield at experimental site of department of crop physiology, Narendra Deva University of Agriculture \& Technology, Kumarganj, Faizabad (U.P.), India. The results showed that the genotypic variability exists for waterlogging tolerance in wheat varieties evaluated under investigation. HD-2009 which is susceptible to waterlogging gave poor performance in terms of growth parameters, biochemical behavior and traits conferring higher yield under waterlogging conditions at ear head emergence stage in sodic soil as compared to HD-2851, KRL-3-4 and KRL-99 wheat varieties. KRL-99 (1.80g yield plant ${ }^{-1}$ ) gave best results followed KRL-3-4 (1.37g yield plant $\left.{ }^{-1}\right)$ by $^{2}$ under waterlogged conditions at ear head emergence stage in sodic soil.
\end{abstract}

Keywords: Biochemical parameter, Growth parameter, Waterlogging tolerance, Yield parameter

\section{INTRODUCTION}

Globally, wheat (Tritium aestivum L.) is world's third largest crop after maize and rice occupies about 218.5 million hectare with an average yield of $3.26 \mathrm{t} \mathrm{ha}^{-1}$ (FAO, 2014). In India, it is second important staple food crop, after rice both in terms of area and with a production of 95.91 million tons from an area of 30 million hectares, thus contributing about 34 per cent of total food grain production (USDA, 2014). In U.P., it ranks first in respect of crop coverage area 19.96 million hectares and production 50.84 million tons but the average productivity is much lower $\left(25.47 \mathrm{q} \mathrm{ha}^{-1}\right)$ than Punjab (42.58 $\mathrm{qha}^{-1}$ ) (Anonymous, 2013-14). India need for food security to produce 109 million metric tones of wheat by 2020 with annual rate of increase in production of about 2.2 per cent while present rate of annual increase is about 1.0 per cent. Salinity, alkalinity and waterlogging (WL) are the major stresses restricting crop stand and yield. Total area under degraded and wastelands in the country stands at 114.01 $\mathrm{M}$ ha, area under salt-affected soils is $6.73 \mathrm{M}$ ha, under acid soils is $16.03 \mathrm{M}$ ha and under waterlogging is 14.29 $\mathrm{M}$ ha (NRSA, 2005). Waterlogging adversely affect 10-15 million ha of wheat production annually on a global level (Sayre et al., 1994), which represents $15-20 \%$ of the 70 million ha. of wheat grown every year. In India, the most common environmental interactions with WL are low or high soil alkalinity. Waterlogging tolerance of wheat may differ depending upon the stage of growth and other environmental factors. Variable results have been reported for yield loss vs. stage of waterlogging. Watson et al. (1976) reported larger reduction in grain yield of wheat, barley and oat when 6 weeks of continuous waterlogging started at 2 weeks after sowing in comparison to waterlogging started at 6 weeks or 10-14 weeks (ear emergence) after sowing. However, Gardner and Flood (1993) suggested that early reproductive stage are more adversely affected by waterlogging than tillering stage due to reduction in grains ear ${ }^{-1}$. Bao (1997) found that for twenty varieties of wheat, the order of intolerance to waterlogging at different stages was booting $>$ jointing $>$ tillering $>$ grain filling. However, no significant difference in waterlogging tolerance of wheat was observed with 4-12 days of waterlogging at tillering vs. flowering in sodic soils of India (Gill et al., 1992). Wheat grain has relatively high content of niacin and thiamine that is why wheat proteins are especially significant. Besides their significance in nutrition, they are principally concerned in providing the 'gluten' which provides spongy cellular texture of bread and baked products. It is consumed in the form of chapaties, puris, suji or rawa. Wheat straw is a good source 
of feed for a large population of cattle in our country. The anoxic medium for wheat roots consisted of a water saturated soil with an oxygen concentration of below a critical threshold estimated to be $0.12 \mathrm{~mol} \mathrm{~m}^{-3}$ water. The results also showed that area which was unfavorable to root growth corresponded to the water table topped with a capillary zone of approximately 6 $\mathrm{cm}$ (Brisson et al., 2002). Strategies that could be used for short term waterlogging tolerance on the other hand are high rates of alcoholic fermentation to ensure energy supply during anoxia high carbohydrate content was substrate for respiration, maintenance of membrane integrity and reduced metabolic leakage, increased efficiency of nutrient uptake and more efficient free radical scavenging system to avoid post water logging oxidative damage. Waterlogging and alkalinity are important soil factors, which affect wheat productivity. Germination and seedling growth are considered to be relatively quite sensitive stages in respect to salinity, sodicity and waterlogging. Though the individual effect of waterlogging, salinity and alkalinity on germination, seedling growth and physiological processes and the combined effects of salinity and waterlogging on wheat and other crops are reported by Dong et al. (1998) and Sharma et al. (2005a). Very little information is available on the combined effects on the alkalinity and WL stress (Sharma et al., 2004). The timing and duration of waterlogging usually depends on irrigation intensity, rainfall and water flow in canals. Therefore, the present investigation was conducted to study the effect of waterlogging tolerance in Wheat (Tritium aestivum L.) at ear emergence stage on growth, biochemical and yield parameters in sodic soil.

\section{MATERIALS AND METHODS}

The investigation was carried out at the experimental site of Department of Crop Physiology, Narendra Deva University of Agriculture \& Technology, Kumarganj, Faizabad (U.P.), India located between 240 to 27.340 $\mathrm{N}$ latitudes and 81.130 to 84.110 E longitudes during Rabi season 2011-12using complete randomized design (CRD) with three replication. The trial was conducted in earthen pots ( 9 inch diameter) using four varieties of wheat i.e. KRL-3-4, KRL-99 (salt tolerance) HD-2009 and HD-2851 (salt susceptible). Each pot was lined with polythene bag and field with $7 \mathrm{~kg}$ well pulverized sodic soil ( $\mathrm{pH} 8.8-9.1)$ collected from natural sodic field. Ten bold and healthy seeds were sown in pots at $2 \mathrm{~cm}$ depth on $24^{\text {th }}$ December, 2011. Thinning was done in each pot after completion of seedling emergence and only three healthy and uniform plants were maintained in each pot. Nitrogen, phosphorus and potash were added at the rate of 120 , 60 and $60 \mathrm{~kg} \mathrm{ha}^{-1}$, through urea, diammonium phosphate (DAP) and muriate of potash, respectively. Half dose of the nitrogen, full dose of phosphorus and total potash were added as a basal dose before sowing of seeds. Remaining nitrogen was added in two equal split doses one at tillering stage and the other at the time of flowering. Standard cultural practices were adopted for normal plant growth. Total number of pots under each variety were divided into four equal groups. The bottom holes of the pots meant for waterlogging were plugged with rubber stopper before waterlogging treatment. $5 \mathrm{~cm}$ of water was ponded onto the soil surface in each pot for ten days at 75 days after sowing DAS at ear emergence stage. At the end of waterlogging treatments, the water was removed from the pots and the stoppers from the bottom holes of the pots were removed for free natural drainage of the excess water. Plant height was measured in $\mathrm{cm}$ from the soil surface up to the tip of the plant. Five tagged plants were measured at end of WL and at maturity stage. Number of tillers and dry weight of five randomly selected plants were counted at the end of WL and at maturity. The maturity duration( the period between sowing to maturity ) under each treatment was recorded and assessed by visual appearance of grains and colour of leaves particularly flag leaf. The crop matures when flag leaf become yellowish and the grains has lost its green chlorophyll colour and turned whitish. The chlorophyll content of leaves was estimated using method given by Arnon (1949) as under:

Total chl. $=\frac{20.2 \times \text { OD } \times 645+8.02+\text { OD } \times 663}{1000 \times \mathrm{W}} \times \mathrm{V}$

Table 1. Effect of waterlogging at ear emergence stage on wheat plant height and biomass/plant.

\begin{tabular}{|c|c|c|c|c|c|c|c|c|}
\hline \multirow{3}{*}{$\begin{array}{l}\text { Varieties/ } \\
\text { treat- } \\
\text { ments }\end{array}$} & \multicolumn{4}{|c|}{ Height $(\mathrm{cm})$} & \multicolumn{4}{|c|}{ Dry weight per plant (g) } \\
\hline & \multicolumn{2}{|c|}{$\begin{array}{c}\text { At the end of water } \\
\text { logging (85DAS) }\end{array}$} & \multicolumn{2}{|c|}{ At maturity } & \multicolumn{2}{|c|}{$\begin{array}{c}\text { At the end of water } \\
\text { logging (85DAS) }\end{array}$} & \multicolumn{2}{|c|}{ At maturity } \\
\hline & NWL & WI & NWL & WL & NWL & WI & NWL. & W4. \\
\hline HD-2009 & 57.65 & 54.05 & 57.65 & 54.05 & 2.67 & 2.17 & 3.00 & 2.66 \\
\hline HD-2851 & 58.45 & 56.84 & 58.45 & 56.84 & 3.13 & 2.60 & 3.67 & 3.35 \\
\hline KRL-99 & 62.39 & 61.33 & 62.39 & 61.33 & 3.72 & 3.28 & 4.71 & 4.43 \\
\hline KRL-3-4 & 73.47 & 70.00 & 73.47 & 70.00 & 3.79 & 3.36 & 4.49 & 4.31 \\
\hline Mean & 62.99 & 60.56 & 62.99 & 60.56 & 3.33 & 2.85 & 3.97 & 3.69 \\
\hline $\mathrm{SEm} \pm$ & 1.27 & 0.90 & 1.27 & 0.90 & 0.06 & 0.05 & 0.08 & 0.05 \\
\hline $\mathrm{CD}$ at $5 \%$ & 3.80 & NS & 3.80 & NS & 0.19 & 0.14 & 0.23 & 0.16 \\
\hline
\end{tabular}

NWL- Non Waterlogging, WL- Waterlogging 
Table 2. Effect of waterlogging on maturity duration of wheat varieties.

\begin{tabular}{ccc}
\hline Varieties/ treat- & \multicolumn{2}{c}{ Days to maturity } \\
\cline { 2 - 3 } ments & NWL & WL \\
\hline HD-2009 & 123.00 & 125.33 \\
HD-2851 & 121.00 & 124.33 \\
KRL-99 & 123.33 & 121.33 \\
KRL-3-4 & 126.67 & 129.00 \\
Mean & 123.50 & 124.99 \\
SEm \pm & 0.92 & 0.65 \\
CD at 5\% & 2.76 & NS \\
\hline
\end{tabular}

NWL- Non Waterlogging, WL- Waterlogging

Whereas,

$\mathrm{V}=$ Final volume of $80 \%$ acetone chlorophyll extract $\mathrm{W}=$ Fresh weight of leaf $(\mathrm{g})$

The total soluble carbohydrate in plant extract was estimated by the method given by Yemm and Willis (1954). Starch was estimated using anthrone reagent method, described by Mc Cready et al. (1950). Catalase activity was assayed colorimetrically according to method given in Analytical biochemistry by Sinha (1972). Peroxides activity was assayed calorimetrically according to method given by Curne and Galston (1959). The yield and yield attributes were recorded at the time of maturity using five randomly selected plants . Ear bearing tiller (EBT) were as certained by counting the total number of ear plant ${ }^{-1}$ under each treatments. The ear length was measured in centimeters from the top (excluding awns) to the base of the ear (collar). Length of 10 randomly selected ears from each treatment was measured and averaged to get length of single ear. The numbers of total grains from five randomly selected ears were counted carefully and average was taken to get the number of grain ear ${ }^{-1}$ .1000 -grains from each treatment were counted and weight for test weight. The grain yield per pot was recorded separately for each variety and expressed as per plant. Biological yield was recorded by weighing the total harvested produce of each pot. The biological yield, thus obtained was expressed as $\mathrm{g}$ plant $^{-1}$.

The statistical analysis of data was done by the method described by Panse and Sukhatme (1978) using completely randomized design (CRD) factorial experiment. The comparison of the treatment means made with the help of least significant differences, calculated as here under:

$$
\begin{aligned}
& \text { C.D. for variety }=\sqrt{\frac{2 \times \mathrm{EMSS}}{\mathrm{T} \times \mathrm{r}} \times \mathrm{t}} \\
& \text { C.D. for waterbgging }=\sqrt{\frac{2 \times \mathrm{EMSS}}{\mathrm{V} \times \mathrm{r}}} \times \mathrm{t}
\end{aligned}
$$

C.D. for variety $\mathrm{x}$ waterbgging $=\sqrt{\frac{2 \times \mathrm{EMSS}}{\mathrm{V} \times \mathrm{r}}} \times \mathrm{t}$ Where;

$\begin{array}{lll}\mathrm{r} & = & \text { Number of replications } \\ \mathrm{T} & = & \text { Treatment } \\ \mathrm{V} & = & \text { Variety } \\ \mathrm{t} & = & \text { Table value at } 5 \% \text { error d.f. } \\ \text { EMSS } & = & \text { Error mean sum of square }\end{array}$

\section{RESULTS AND DISCUSSION}

All wheat varieties showed suppressed plant height (poor growth) under waterlogging conditions (Table 1). Waterlogging tolerant varieties KRL-3-4, KRL-99 and HD-2851 showed higher plant height than susceptible variety HD-2009 at all the growth stages. Plant height was more reduced at vegetative stage than at booting stage under waterlogging treatment. The reason for this as shown by Savita et al. (2004) is that root development is higher at vegetative stage and at waterlogged condititions the root system got destroyed, ultimately effecting growth and development of the plant (Baranwal and Singh, 2002, Neog et al., 2002 and Sharma et al., 2005a ).

Considering the effect of waterlogging on number of tillers and dry weight per plant $(\mathrm{g})$, the results indicated

\begin{tabular}{|c|c|c|c|c|c|c|c|c|c|c|c|c|c|c|}
\hline \multirow{3}{*}{$\begin{array}{l}\text { Varieties/ } \\
\text { treat- } \\
\text { ments }\end{array}$} & \multicolumn{4}{|c|}{ Number of tillers/plant } & \multicolumn{4}{|c|}{ Number of grains (wt.)/ear) } & \multirow{2}{*}{\multicolumn{2}{|c|}{$\begin{array}{l}\text { Grain yield/ } \\
\text { spike (g) }\end{array}$}} & \multirow{2}{*}{\multicolumn{2}{|c|}{$\begin{array}{c}\text { Biological } \\
\text { yield /plant } \\
\text { (g) }\end{array}$}} & \multirow{2}{*}{\multicolumn{2}{|c|}{$\begin{array}{l}\text { Harvest index } \\
(\%)\end{array}$}} \\
\hline & \multicolumn{2}{|c|}{$\begin{array}{l}\text { At the end of } \\
\text { water logging } \\
\text { (85DAS) }\end{array}$} & \multicolumn{2}{|c|}{ At maturity } & \multicolumn{2}{|c|}{$\begin{array}{l}\text { At the end of } \\
\text { water logging } \\
\text { (85DAS) }\end{array}$} & \multicolumn{2}{|c|}{ At maturity } & & & & & & \\
\hline & NWL & $\mathbf{W L}$ & NWL & $\mathbf{W L}$ & NWL & $\mathbf{W L}$ & $\begin{array}{l}\text { NW } \\
\text { L }\end{array}$ & $\mathbf{W L}$ & $\begin{array}{l}\mathbf{N W} \\
\mathrm{L}\end{array}$ & $\mathbf{W L}$ & $\begin{array}{l}\text { NW } \\
\text { L }\end{array}$ & $\mathbf{W L}$ & NWL & $\mathbf{W L}$ \\
\hline HD-2009 & 57.65 & 54.05 & 57.65 & 54.05 & 2.67 & 2.17 & 3.00 & 2.66 & 1.56 & 0.75 & 3.00 & 2.66 & 52.11 & 28.32 \\
\hline HD-2851 & 58.45 & 56.84 & 58.45 & 56.84 & 3.13 & 2.60 & 3.67 & 3.35 & 2.07 & 0.81 & 3.67 & 3.35 & 47.85 & 24.11 \\
\hline KRL-99 & 62.39 & 61.33 & 62.39 & 61.33 & 3.72 & 3.28 & 4.71 & 4.43 & 2.45 & 1.80 & 4.71 & 4.43 & 55.37 & 24.59 \\
\hline KRL-3-4 & 73.47 & 70.00 & 73.47 & 70.00 & 3.79 & 3.36 & 4.49 & 4.31 & 1.60 & 1.37 & 4.49 & 4.31 & 49.95 & 31.81 \\
\hline Mean & 62.99 & 60.56 & 62.99 & 60.56 & 3.33 & 2.85 & 3.97 & 3.69 & 2.10 & 1.24 & 3.97 & 3.69 & 51.32 & 29.71 \\
\hline & $\mathrm{V}$ & WL & V & WL & V & WL & V & WL & V & WL & V & WL & V & WL \\
\hline $\mathrm{SEm} \pm$ & 1.27 & 0.90 & 1.27 & 0.90 & 0.06 & 0.05 & 0.08 & 0.05 & 0.08 & 0.06 & 0.08 & 0.05 & 1.38 & 0.97 \\
\hline $\mathrm{CD}$ at $5 \%$ & 3.80 & NS & 3.80 & NS & 0.19 & 0.14 & 0.23 & 0.16 & 0.25 & 0.18 & 0.23 & 0.16 & 4.13 & 2.92 \\
\hline
\end{tabular}

Table 3. Effect of waterlogging on yield and yield attributes of wheat varieties .

NWL- Non Waterlogging, WL- Waterlogging 
that more number of tiller and dry weight per plant (g) is obtained among waterlogging tolerance varieties i.e. KRL-99, KRL-3-4 as compared to susceptible variety HD-2009 and HD-2851 at various growth stages (Table 1).The slow growth during submergence maintains high carbohydrate supply and hence prolonged energy supply in maize and rice resulting decreased number of tillers which ultimately resulted in reduced plant biomass (Baranwal and Singh, 2002, , Neong et al, 2002 and Singh et al, 2002, Sharma et al, 2005a ; Shao et al. 2010) .

Under waterlogging treatment, the phenological development of all the four wheat varieties were affected because root zone saturation induced a delay in the phenological events associated with the reproductive phase. Waterlogging imposed at ear emergence stage showed delay in 50\% flowering period and maturity duration. Genotypic variability was also observed among tested wheat varieties. In variety HD-2009 there was delay in $50 \%$ flowering period but no reduction in maturity duration, resulting in forced ripening and reduced yields (Savita et al., 2004) (Table 2).

Yield is an outcome of all metabolic processes and growth events which occurs during a life-cycle of plant. Any abiotic or biotic stress occuring during their growth and development period adversely effect the potential productivity of the crop. The waterlogged tolerant varieties KRL-3-4 and KRL-99 showed less effect on yield contributing components namely number of ears plant, ${ }^{-1}$ number of grains ears, ${ }^{-1}$ grain yield spike, $^{-1}$ biological yield plant ${ }^{-1-}$ and harvest index due to waterlogging as compared to susceptible varieties HD-2581 and HD-2009(Table 3).

Maximum reduction in the above traits were observed when waterlogging was imposed at vegetative and flowering stage followed by vegetative stage and least reduction was noted when stress was applied only at the ear emergence stage. Waterlogging for a long period resulted in poor aeration and nutrient stress which in turn decreases grain yield (Sharma et al., 2005a). Waterlogging treatment resulted in reduction in chlorophyll content in all the wheat varieties. The loss of chlorophyll could be due to high ethylene content in soil and its transport to leaves or disbalance nitrogen metabolism which induces chlorosis of leaves. In addition it could also be due to lack of efficient scavenging system, which protect the membrane damage and chlorophyll degradation(Sharma et al., 2005b, Das and Sarkar, 2003, Baranwal and Singh, 2002, Neog et al., 2002 and Prasad et al., 2004, Shao et al. 2010). The chlorophyll content was drastically reduced in susceptible variety HD-2009 as compared to the other wheat varieties HD-2851, KRL-3-4 and KRL-99 at all growth stages. HD-2009. Interesting to note worthy is the variable responses of varieties indicating differential defense mechanism in tolerant and susceptible varieties. Reduction in soluble carbohydrate during waterlogging is one of the crucial biochemical events which affect the survival and growth during waterlogging treatments. The reduction is possible due to reduced photosynthesis during waterlogging and utilization of existing carbohydrate in anaerobic root respiration during waterlogging.

Loss of chlorophyll reported earlier could be responsible for reduced photosynthesis and carbohydrates under waterlogging conditions. All the wheat varieties have higher carbohydrate before waterlogging treatments. Waterlogging decreased the carbohydrate content in all the wheat varieties at all the crop growth stages but reduction was more in HD-2009 and HD2851 as compared to tolerant variety KRL-99 and KRL -3-4. Low carbohydrate could also be due to reduced mineral content and attired carbohydrate synthesis, loading and transport to roots. Decreased root activity may be the another reason for reduced nutrient uptake (Mielke and Schaffer ,2010). Also, the synthesis of ATP got reduced due to highly anaerobic condition under waterlogging treatment (Table 4). The developing grains of wheat genotypes differ in their starch and sugar content (Kumar and Singh, 1981).

All the varieties recorded maximum enzyme activity at 90 DAS under control conditions. The KRL-99 and KRL-3-4 showed higher starch activity under control as compared to HD-2009 and HD-2851. Under tem-

Table 4. Effect of waterlogging on biochemical parameters of wheat varieties under sodic soil.

\begin{tabular}{|c|c|c|c|c|c|c|c|c|c|c|}
\hline \multirow[t]{2}{*}{$\begin{array}{l}\text { Varieties/ } \\
\text { treatments }\end{array}$} & \multicolumn{2}{|c|}{$\begin{array}{c}\text { Total chlorophyll } \\
\text { Content } \\
\text { (mg/g fresh weight in } \\
\text { leaves) }\end{array}$} & \multicolumn{2}{|c|}{$\begin{array}{c}\text { Total soluble carbo- } \\
\text { hydrate } \\
\text { (mg/g dry weight) }\end{array}$} & \multicolumn{2}{|c|}{$\begin{array}{l}\text { Starch } \\
\text { Content } \\
\text { ( mg/g dry } \\
\text { weight) }\end{array}$} & \multicolumn{2}{|c|}{$\begin{array}{c}\text { Catalase } \\
\text { Activity } \\
\text { (unit/g fresh wt./ } \\
\text { min.) }\end{array}$} & \multicolumn{2}{|c|}{$\begin{array}{c}\text { Peroxides } \\
\text { activities } \\
\text { (unit/g fresh wt./ } \\
\text { min.) }\end{array}$} \\
\hline & NWL & $\mathbf{W L}$ & NWL & $\mathbf{W L}$ & NWL & WL & NWL & $\mathbf{W L}$ & NWL & $\mathbf{W L}$ \\
\hline HD-2009 & 2.63 & 1.77 & 84.89 & 53.10 & 74.60 & 43.77 & 118.97 & 234.97 & 144.97 & 204.97 \\
\hline HD-2851 & 2.49 & 1.85 & 89.30 & 65.80 & 77.30 & 53.93 & 120.97 & 220 & 128 & 218.00 \\
\hline KRL-99 & 2.86 & 2.40 & 98.50 & 85.60 & 81.50 & 70.30 & 124.97 & 280 & 134.97 & 303.33 \\
\hline KRL-3-4 & 2.67 & 2.31 & 95.20 & 85.20 & 86.40 & 71.80 & 116.97 & 310 & 140 & 310.00 \\
\hline Mean & 2.66 & 2.08 & 91.97 & 72.40 & 79.95 & 59.95 & 120.47 & 261.24 & 136.98 & 259.08 \\
\hline SEm \pm & 0.05 & 0.03 & 1.66 & 1.17 & 1.71 & 1.21 & 4.18 & 2.96 & 10.72 & 7.58 \\
\hline $\mathrm{CD}(0.05)$ & 0.15 & 0.10 & 4.97 & 3.51 & 5.13 & 3.63 & 12.55 & 8.87 & 32.14 & 22.73 \\
\hline
\end{tabular}

NWL- Non Waterlogging, WL- Waterlogging 
perature stress, current photosynthesis got limited which leads to degradation of starch into soluble sugar to meet the plant energy requirement.

The oxidative damage to cellular component is limited under control condition due to efficient processing of reactive oxygen species (ROS) through a well coordinated and rapidly responsive antioxidant system consisting of several enzymes and redox metabolites. However, under various abiotic stresses the extent of ROS production exceeds the antioxidant defense capacity of the cell, resulting in cellular damage. It is clear from the data that there was a significant increase in the antioxidant enzymes activity in response to late sowing. As far as, varietal response was concerned, under control, KRL3-4 and KRL-99 showed greater increase in activities of catalase and peroxides than HD-2009 and HD-2851. This indicates that these varieties have been better scavenging capacity and higher tolerance to heat stress than other varieties. Thus results of the investigation showed that waterlogging severely affects yield and yield components of all the wheat varieties because yield is a summation of all metabolic processes and growth events during lifecycle of a crop plant and any abiotic or biotic stress during their growth and development adversely influenced the potential productivity of crops (Table 3 ) .

\section{Conclusion}

Waterlogging at ear emergence stage did not show any significant reduction in plant height (max. $70 \mathrm{~cm}$ and $\min$. $54.05 \mathrm{~cm}$ ), number of tillers ( $\max .3$ and $\min .2$ ) and dry weight (max. $3.36 \mathrm{~g}$ and $\mathrm{min} .2 .17 \mathrm{~g}$ ) in tolerant/ susceptible varieties but resulted in significant reduction in leaf total chlorophyll (max. $2.4 \mathrm{mg} \mathrm{g}^{-1}$ and min. $1.77 \mathrm{mg} \mathrm{g}^{-1}$ ), total soluble carbohydrate (max. $85.6 \mathrm{mg} \mathrm{g}^{-1}$ and min. $53.1 \mathrm{mg} \mathrm{g}^{-1}$ ) and starch content (max. $71.8 \mathrm{mg} \mathrm{g}^{-1}$ and min. $43.77 \mathrm{mg} \mathrm{g}^{-1}$ ) . Tolerant varieties (KRL-3-4 and KRL-99) showed comparatively less reduction in above treatments as compared to susceptible varieties (HD-2851 and HD-2009). Waterlogging at ear emergence stage induced increase in catalase ( $\max .310$ and $\min .220)$ and peroxidase activity (max. 310 and $\min .204$ ), however, tolerant variation had more increase than susceptible one. Waterlogging at ear emergence stage caused increase in maturity duration of all wheat varieties, however, effect was non-significant. Yield components like number of ear plant ${ }^{-1}$, number of grains ear ${ }^{-1}$, biological yield and harvest index showed non-significant decrease under waterlogging over non-waterlogging in tolerant/ susceptible varieties. However, harvest index (max. 31.81 and min. 24.1) and grain yield plant ${ }^{-1}$ (max. $1.8 \mathrm{~g}$ and min. $0.73 \mathrm{~g}$ ) decreased due to waterlogging and tolerant varieties showed less yield reduction as compared to susceptible one.

\section{REFERENCES}

Anonymous (2013-14). Agricultural statistics division, Directorate of economics and statistics, New Delhi from agricoop.nic.in/Annualreport2013-14/artp13-14ENG.pdf.
Arnon, D.I. (1949). Copper enzymes is isolated chloroplast, polyphenyloxidase in Beta vulgaris. Plant Physio.24: 115.

Bao, X. (1997). Study on identification stages index of waterlogging tolerance in various genotype (Triticum aestivum L.). Acta Agriculture Shanghai, 13 (2) : 32-38.

Baranwal, Sarita and Singh, B.B. (2002). Effect of waterlogging on growth, chlorophyll and saccharides content in maize genotypes. Indian J. Plant Physiol., 7 (3) : 246251.

Brisson, N.; Rebiere, B.; Zimmer, D. and Renault, P. (2002). Response of the root system of a winter wheat crop to waterlogging. Plant \& Soil, $243: 43-55$.

Curne, D.C. and Galston, A.W. (1959). Inverse effect of gibberellins in peroxidase activity during growth in dwarf strain of pea and corn. Pl. Physiol., 34 : 416-418.

Das, K.K. and Sarkar, R.K. (2003). Post flood changes on the status of chlorophyll, carbohydrate \& nitrogen content and its association $w$ with submergence tolerance in rice. Plant Arciver, 1 (1-2): 15-19.

Dong, D.F., Luo, B.S. and Chen, D.Q. (1998). Comparative study on some physiological characteristics of wheat waterlogged at seedling \& booting stage. J. Guangxi Agri. Univ., 17 (4) : 351-355.

FAO (2014). Food and Agriculture Organisation of the united nations statistics division www. Faostat3.fao.org/ browse $/ \mathrm{q} / * / \mathrm{e}$ (accessed on 21 August, 2015)

Gardner, W.K. and Flood, R.G. (1993). Less waterlogging damage with long season wheat, Cereal Res. Comm., $21: 337-343$.

Gill, K.S., Aligadarand and Singh, K.N. (1992). Response of wheat genotypes to sodicity in association with waterlogging at different stages of growth. Indian J. Agri. Sci., 62 (12) : 124-129.

Kumar, R. and Singh, R. (1981). Free sugars and their relationship with rain size and starch content in developing wheat grains. J. Sci. Food and Agri., 32 :229-234.

Mc Cready, R.M., Guggols, J., Silviers, V. and Owen, H.S. (1950). Determination of starch and amylase in vegetable. Ann. Chem., 22 : 1156-1158.

Mielke, M.S., Schaffer, B. (2010). Photosynthetic and growth responses of Eugenia uniflora L. seedlings to soil flooding and light intensity. Environ. Exp. Bot. 68: 113-121.

Neog, B., Gogoi, Nirmali and Baruah, K.K. (2002). Morphological changes associated with waterlogging changes associated with waterlogging in rice (Oryza sativa L.). Indian Journal of Agricultural Sciences, 72 (7) : 404407.

NRSA (2005). Wasteland Atlas of India. Ministry of Rural Development and National remote sensing center Publ., NRSA, Hyderabad.

OECD- FAO (2013). Agricultural outlook: Highlights. OECD Agriculture Statistics from www.oecdilibrary.org/ agriculture.

Panse, V.G. and Sukhatme, P.V. (1978). Statistical methods for agricultural workers. Indian Council of Agricultural Research, New Delhi 3:147-148.

Prasad, Shambhoo; Ram, P.C. and Singh, Uma (2004). Effect of waterlogging duration on chlorophyll content, nitrate reductase activity, soluble sugar and grain yield of maize. Ann. Plant Physiol., 18 (1) : 1-5

Savita, U.S., Rathore, T.R. and Mishra, H.S. (2004). Response of some maize genotypes to temporary waterlogging. J. Plant Biol., 31 (1) : 29-36. 
Sayre, K.D., Van Ginkel, K., Raja Ram andS., Qritzmonasperio, I. (1994). Tolerance to waterlogging losses in sping bread wheat effect of time of onset on expereffion. In : Annual Wheat Newsletter No. 14 Colorado State University pp 165-171.

Shao, G.C., Yu, S.E., Liu, N. (2010). Study on continuous days of water logging and excessive soil water as drainage index of wheat. Trans. CSAE 26: 56-60.

Sharma, D.P., Singh, M.P., Gupta, S.K. and Sharma, N.L. (2005a). Response of pigeonpea to short-term water stagnation in a moderately sodic soil under field conditions. Journal of The Indian Society of Soil Science, 53 (2) : 243-248.

Sharma, P.K., Sharma, S.K. and Goswami, C.L. (2005b). Individual and combined effects of alkalinity and waterlogging stresses on germination and seedling growth in two varieties of wheat (Triticum aestivum L.). J. Plant Bio., 32 (2) : 133-137.

Sharma, S.K., Praveen, K.S., Setter, T.L. and Singh, K.N. (2004). Genetic diversity in waterlogging tolerance of wheat genotypes in neutral and sodic soil at the seed germination stage. In :Proceeding of International Conference of Sodicity, Lucknow, pp. 264-267.

Singh, Anuradha, Ram, P.C., Singh, A.K. and Singh, B.B. (2002). Phenotypic differences in response to submergence in rainfed lowland rice. Indian J. Plant Physiol., 7 (4) : 309-313.

Sinha, S.K. (1972). Chlorometric assay of catalase. Analytical Biochemistry, 47 ; 2-5.

USDA (2014). United states Department of Agriculture Foreign Agricultural service www.fas.usda.gov/psdonline, accessed on 21 August 2015

Watson, E.R., Lapins, P. and Barron, R.J.W. (1976). Effect of waterlogging on the growth, grain and straw yield of wheat, barley and oat. Aust. J. Exp. Agri. Anim. Husb., $16: 114-122$.

Yemm E. W. and Willis A. J. (1954). The estimation of carbohydrates in plant extracts by anthrone. Biochem J. 57 (3): 508-514. 